\title{
МЕДСЕСТРИНСЬКИЙ МЕНЕДЖМЕНТ У СВОЄЧАСНІЙ ДІАГНОСТИЦІ ТА ПРОФІЛАКТИЦІ КЛІМАКТЕРИЧНИХ РОЗЛАДІВ
}

\author{
Л. М. Маланчук, А. Е. Шевченко, А. С. Маланчук, С. Л. Маланчук, \\ T. А. Небесьо
}

\author{
Тернопільський національний медичний університет \\ імені І. Я. Горбачевського МОЗ Украӥни
}

Стаття присвячена ролі медсестринського менеджменту в своєчасній профілактиці та діагностиці симптомів клімактеричного синдрому в жінок пострепродуктивного віку.

\section{NURSING MANAGEMENT IN OPPORTUNE DIAGNOSTICS AND PREVENTION OF CLIMACTERIAL DISORDERS}

\author{
L. M. Malanchuk, A. E. Shevchenko, A. S. Malanchuk, S. L. Malanchuk, \\ T. A. Nebeso
}

\section{Horbachevsky Ternopil National Medical University}

The article is devoted to the role of the nursing management in the opportune prevention and diagnosis of the menopausal syndrome symptoms in women of postproductive age.

Вступ. За прогнозом ВООЗ, до 2030 р. в Україні у періоді постменопаузи перебуватиме 13,2 млн жінок. Враховуючи середній вік менопаузи в нашій країні - 48 років та середню тривалість життя жінки в державі - 71 рік, близько третини свого життя (23 роки) вони будуть перебувати у гіпоестрогенному стані. Вже у віці 40+, коли настає час максимальної втрати оваріального резерву, пацієнтки починають відчувати перші прояви клімаксу: найчастіше це проявляється симптомами припливу жару, рясним нічним потовиділенням, неспокоєм, тривожністю та ін. [1].

Необхідно враховувати той факт, що значна частина жінок пострепродуктивного віку вже має в анамнезі гінекологічну патологію, зокрема різноманітні хірургічні втручання на органах малого таза (аж до пангістеректомій), що суттєво прискорює процес старіння разом із патологічним клімаксом [2].

Проблеми клімактерію мають не лише медичний, але й соціальний аспекти. Важливим негативним фактором у розвитку менопаузального синдрому варто розглядати економічну, демографічну та екологічну ситуації в країні, які суттєво впливають на якість життя жінки 40+ [1, 3].
За умов розвитку та удосконалення медсестринського процесу, функції медичної сестри значно розширені й не обмежуються простим виконання вказівок лікаря. На неї покладено основні обов'язки догляду за пацієнтами: профілактика захворювань, збереження здоров'я, реабілітація і полегшення страждань. Формування професійної компетентності медичних сестер - це складний, поетапний процес підготовки висококваліфікованого компетентного спеціаліста з медсестринства, що володіє суміжними медичними спеціальностями, готового до професійного зростання, здатного до самоосвіти та самовдосконалення, передбачає індивідуальний стиль професійної діяльності фахівців визначеного профілю.

Вона має бути лідером, менеджером, педагогом і психологом. За умов діджиталізації місія медичної сестри розширює свої повноваження та можливості, особливо, що стосується поінформованості пацієнтів із різних вікових проблем.

Таким чином, у профілактиці та своєчасній діагностиці симптомів клімактеричного синдрому особлива роль належить медичній сестрі сімейної медицини [4].

(ㄷ Л. М. Маланчук, А. Е. Шевченко, А. С. Маланчук, С. Л. Маланчук, Т. А. Небесьо, 2020 
Основна частина. У житті кожної жінки настає період, коли на фоні генетично запрограмованих інволюційних змін в усьому організмі процеси згасання домінують в репродуктивній сфері. Результатом цього «виключення» $\epsilon$ поступове зменшення оваріального резерву і, як наслідок, втрата дітородної функції та наступне припинення менструацій [1].

Згідно з результатами 10-річних когортних досліджень STRAW+10 (Stages of Reproductive Aging Workshop), клініко-гормональні характеристики етапів старіння репродуктивної системи представлені 4 періодами клімактерію: періодом менопаузального переходу, менопаузи, перименопаузи і постменопаузи.

Перименопауза починається у віці 40-45 років і завершується з останньою менструацією та характеризується варіабельністю менструальних циклів. У цей період можуть з'являтися вазомоторні та психоемоційні симптоми дефіциту естрогенів, відзначаються варіабельні рівні фолікулостимулювального гормону (ФСГ), естрадіолу (Е2), зниження рівня прогестерону, інгібіну В і антимюлерового гормону [2].

У рамках соціально-інформаційного проекту: «3береження якості життя та соціальної активності жінок у пострепродуктивному віці», який був впроваджений в усіх регіонах України, проведено анкетування та статистичний аналіз даних менопаузальної рейтингової шкали (MRS) пацієнток Комунального некомерційного підприємства «Центр первинної медико-санітарної допомоги № 2» м. Запоріжжя; оцінено ступінь тяжкості клімактеричного синдрому в респондентів дослідження; проведено інформаційно-просвітницьку роботу серед жінок амбулаторного обліку віком 40+ [1, 3].

Для оцінки ступеня тяжкості проявів менопаузального синдрому 52 учасниці програми віком 40+ дали відповідь на запитання MRS шкали (рис. 1).

За результатами опитування виявлено, що найчастіше у жінок 40+ поряд із психологічними та соматовегетативними розладами спостерігалися проблеми сексуального характеру, сухість піхви.

Відчуття припливу жару та епізоди нічної пітливості мали легкі та помірно виражені ознаки у 39 (75 \%) пацієнток, тоді як оцінка в 3-4 бали спостерігалася у 3 пацієнток. $19 \%$ респондентів не відзначали прояви вегетативних симптомів менопаузального синдрому. У 6 \% випадків спостерігалися максимально виражені симптоми припливу жару та рясної пітливості.

36 (69 \%) пацієнток з групи обстеження скаржилися на неприємні відчуття в ділянці серця: немотивоване прискорене серцебиття, порушення серцевого ритму, відчуття стиснення за грудиною.

У 52 \% випадків прояви прискореного серцебиття були незначно та помірно виражені. Суттєвий вплив неприємних відчуттів в ділянці серця на самопочуття жінок спостерігали в $17 \%$.

Проблеми із засинанням, прокиданням вночі, передчасним пробудженням мали місце у 73 \%. У жодному випадку не спостерігали порушення сну в надзвичайно вираженій формі.

Відчуття пригнічення, суму, плаксивість, різка зміна настрою, апатичність були характерними симптомами клімактеричного синдрому для 32 жінок пострепродуктивного віку. Варто зауважити, що третина пацієнток не відзначала цього прояву, а у 8 \% випадків спостерігалася вираженість депресивного настрою.

Внутрішнє напруження, агресивність, дратівливість, знервованість незначно турбували 22 (42 \%) жінки, помірно виражений характер був у 11 (21\%) пацієнток, значно виражений -у 12 \% випадків. Більшість респондентів дослідження не відзначала внутрішній неспокій та панічний настрій. Незначно та помірно виражені симптоми відчуття стурбованості виявлено у 20 жінок.

Суттєвий вплив на зміну якості життя та соціальної активності жінок 40+ мало фізичне та психічне виснаження. У 88 \% спостерігали зниження загальної працездатності, погіршення пам'яті, концентрації уваги та забудькуватості [2]. Лише у 6 пацієнток були відсутні ці розлади. У 65 \% випадків ці зміни мали помірно виражений та незначний характер, тоді як у 23 \% спостерігали значно та надзвичайно виражене фізичне та психічне виснаження.

Суттєві зміни відзначили жінки пострепродуктивного віку у статевому житті. 43 (83 \%) пацієнтки скаржилися на зміну лібідо, зниження сексуальної активності, відсутність задоволення від сексу.

Встановлення довірливих стосунків між пацієнтами та медичним персоналом дало можливість своєчасно привернути увагу жінок на проблеми вікових інволюційних змін статевої сфери. Проведена оцінка якості статевих стосунків виявила суттєві зміни останніх та ризики негативних наслідків для сімейного життя [5].

у більшості випадків зниження сексуальної активності поєднувалося із фізичним та психологічним виснаженням, емоційно-вегетативними порушеннями. Саме цей аспект порушень мав найчисленнішу групу надзвичайно виражених симптомів. 


\section{Menopause Rating Scale (MRS)}

Which of the following symptoms apply to you at this time? Please, mark the appropriate box for each symptom. For symptoms that do not apply, please mark 'none'.

Symptoms:

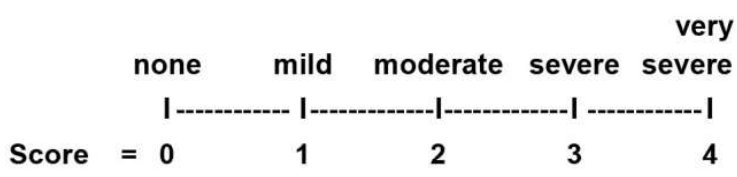

1. Hot flushes, sweating

(episodes of sweating)

2. Heart discomfort (unusual awareness of heart beat, heart skipping, heart racing, tightness).

3. Sleep problems (difficulty in falling asleep, difficulty in sleeping through, waking up early)

4. Depressive mood (feeling down, sad, on the verge of tears, lack of drive, mood swings)

5. Irritability (feeling nervous, inner tension, feeling aggressive)

6. Anxiety (inner restlessness, feeling panicky)

7. Physical and mental exhaustion (general decrease in performance, impaired memory, decrease in concentration, forgetfulness) .....

8. Sexual problems (change in sexual desire, in sexual activity and satisfaction)

9. Bladder problems (difficulty in urinating, increased need to urinate, bladder incontinence).

10. Dryness of vagina (sensation of dryness or burning in the vagina, difficulty with sexual intercourse)

11. Joint and muscular discomfort (pain in the joints, rheumatoid complaints)

PUс. 1. Шкала для оцінки тяжкості проявів менопаузального синдрому (MRS).

Такі симптоми, як нетримання сечі, диспареунія, ніктурія не спостерігали у майже половини пацієнток, а у решти жінок отримали оцінку в 1-2 бали. Урогенітальні прояви клімактеричного синдрому турбували більшість респондентів проекту: 22 жінки спостерігали невираженість симптомів, 14 - помірну вираженість, 5 - значну вираженість.

Згідно з даними шкали MRS, проблеми кістковом'язової системи мали місце у більшості спостережень. Незначно виражені неприємні відчуття у суглобах і м'язах та скарги подібні до ревматичних захворювань висловили 19 жінок, в одному випадку симптоми втрати кісткової маси та асоційовані з ним проблеми мали значно виражений характер. 8 пацієнток оцінили симптоми у 2 бали.

За даними менопаузальної рейтингової шкали, більшість симптомів клімактеричного синдрому були оцінені в 0-2 бали (незначно та помірно виражені). У 48 (92\%) пацієнтів спостерігали виражені симптоми клімактеричного синдрому, а 8 (15\%) жінок оцінили прояви патологічного клімаксу в максимальну кількість балів - 4. У однієї пацієнтки були дуже виражені припливи жару, в 2 - скарги з боку серцево-судинної системи, по одній пацієнтці скаржилися на тяжку депресію та виснаження та 3 пацієнтки вказали на значні розлади сексуального життя (рис. 2). 


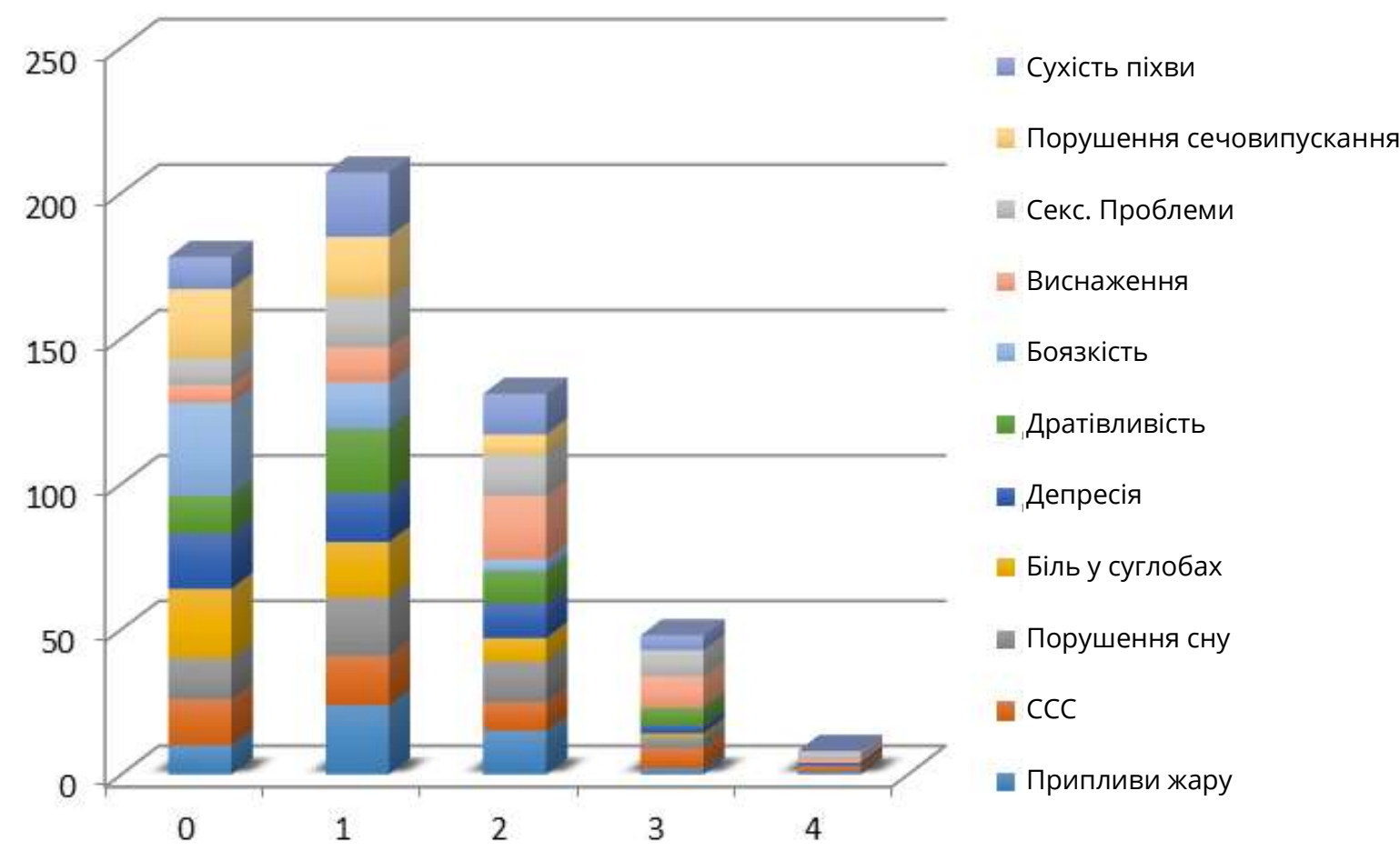

PUс. 2. Оцінка ступеня тяжкості симптомів клімактеричного синдрому в респондентів дослідження.

Згідно з оцінкою за шкалою MRS, у 8 (15 \%) жінок спостерігали легкі прояви менопаузального синдрому, в 37 (71 \%) пацієнток симптоми клімактеричного синдрому мали помірно виражений характер та 7 (14 \%) респондентів скаржилися на тяжкий перебіг менопаузи (рис. 3).

Окрім того, вони мали змогу отримати кваліфіковану консультацію з питань профілактики та лікування менопаузальних розладів.
Проведена широкомасштабна інформаційна кампанія серед жіночого населення в мас-медіа привернула увагу до проблем пострепродуктивного віку жінок та сприяла впровадженню конкретних методичних рекомендацій для практичної діяльності не лише лікарів загальної практики - сімейної медицини, але й середнього медичного персоналу.

Висновки. Проведена освітня робота серед жіночого населення віком 40+ сприяла максимальній

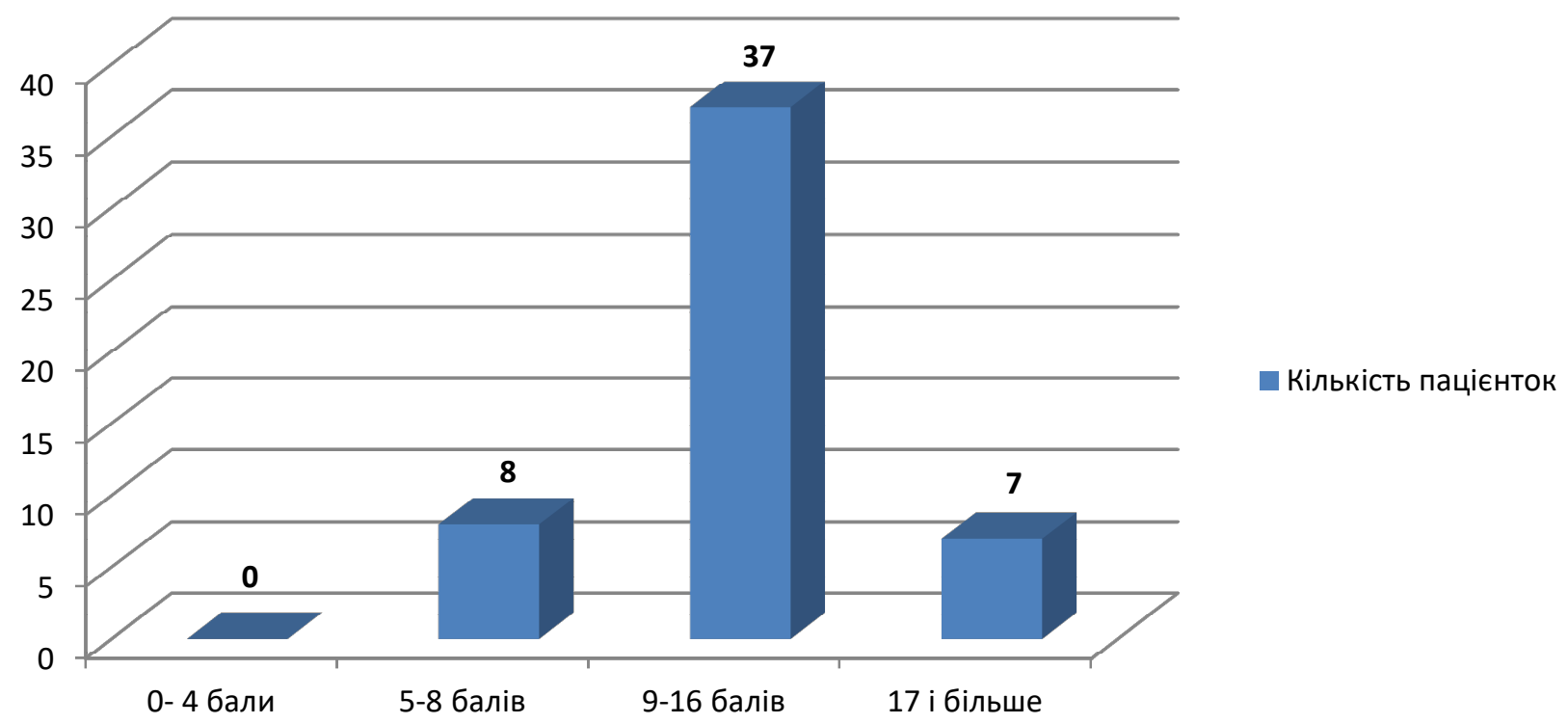

PUC. 3. Динаміка інтенсивності проявів менопаузального синдрому в жінок за шкалою MRS. 
інформованості пацієнток із питань менопаузального синдрому (симптомів, ризиків, режиму харчування, фізичних та психологічних вправ та ін.). Соціальноіндивідуальні, загальнонаукові, інструментальні, загальнопрофесійні та спеціалізовано-професійні компетенції медичної сестри сімейної медицини до-

\section{СПИСОК ЛІТЕРАТУРИ}

1. Татарчук Т. Ф. Національний консенсус щодо ведення пацієнток у клімактерії / Т. Ф. Татарчук, Тобі де Вільєрс // Репродуктивная эндокринология. - 2016. № 1 (27). - С. 8-25.

2. Порівняльна характеристика ранніх клімактеричних симптомів у жінок з хірургічною та природною менопаузою / О. М. Барна, С. О. Галникіна, Т. М. Ониськів, О. Я. Буратинська // Вісник наукових досліджень. - 2002. № 3. - С. 76-79.

3. Татарчук Т. Ф. Проблема клімактерію у практиці сімейного лікаря / Т. Ф. Татарчук, О. А. Єфименко, зволили під час надання медичних послуг в умовах Комунального некомерційного підприємства «Центр первинної медико-санітарної допомоги № 2» м. Запоріжжя зробити реальний внесок у збереження якості життя та покращення соціальної активності жінок пострепродуктивного віку.

К. М. Дубовка // Репродуктивная эндокринология. 2012. - № 4 (6). - C. 22-32.

4. Knowledge and attitude of primary care doctors towards management of postmenopausal symptoms / Abeer A. Al-Eassa, Abeer M. Al-Fadel, Maryam A. Al-Ajmi [et al.] // Journal of Medicine. - Vol. 48, Issue 2. - P. 167-173.

5. Bittner V. Menopause, age, and cardiovascular risk: A complex relationship // Journal of the American College of Cardiology. - Vol. 54, Issue 25. - P. 2374-2375.

Отримано 23.03.20 